\title{
PENGARUH RADIASI LAMPU MERKURI TERHADAP BERAT DAN PANJANG FETUS MENCIT (Mus musculus L.)
}

\section{EFFECS OF MERCURY LAMP RADIATION ON BODY WEIGHT AND LENGTH OF MICE (Mus musculus L.) FETUS}

\author{
Dewi Selvia ${ }^{1}$, Nuning Nurcahyani ${ }^{1}$, Hendri Busman ${ }^{1}$ \\ ${ }^{1}$ Jurusan Biologi FMIPA Universitas Lampung \\ E-mail: dhewi.selvia@mail.com
}

Jurusan Biologi FMIPA Universitas Lampung

Jl. Soemantri Brojonegoro No.1, Bandar Lampung, Lampung, Indonesia, 35145

\begin{abstract}
Abstrak
Radiasi gelombang elektromagnet yang dipancarkan oleh lampu merkuri dapat mem- pengaruhi proses pembelahan sel embrio mencit. Radiasi yang mengenai sel embrio tersebut akan menyebabkan pertumbuhan tidak normal dan mempengaruhi morfologi fetus mencit. Tujuan penelitian ini adalah untuk mengetahui pengaruh radiasi lampu merkuri terhadap berat dan panjang fetus mencit (Mus musculus L.). Penelitian ini menggunakan pemajanan lampu merkuri selama 18 hari sebagai bentuk perlakuan terhadap mencit bunting. Hasil analisis ragam berat badan fetus dan panjang fetus menunjukkan perbedaan nyata terhadap kontrol, dan uji lanjut BNT 5\% pada berat badan menunjukkan hasil bahwa semua perlakuan memiliki pengaruh yang berbeda, kecuali pada perlakuan pemajanan 12 jam/hari dan 16 jam/hari menunjukkan pengaruh yang tidak berbeda. Panjang fetus kontrol menunjukkan perbedaan dengan semua perlakuan, tetapi pemajanan 4 jam/hari tidak berbeda dengan pemajanan 8 jam/hari, begitu juga antara pemajanan 12 dan 16 jam/hari tidak menunjukkan pengaruh yang berbeda.
\end{abstract}

Kata kunci : Radiasi, fetus, mencit (Mus musculus L.)

\begin{abstract}
Electromagnetic radiation of Mercury lamp can affect embryo cells division process during mice gestation. The radiation on the mice embryo cells can cause growth and morphological abnormalities. The purpose of the research was to investigate the influence of mercury lamp radiation to body weight and length on mice fetus (Mus musculus L.). The mercury lamp was exposed to gestated mice for 18 days. The fetus body weight and length were analyzed using the oneway Anova. The results showed that there were significant differences among the trated mice and control group. The LSD (Least Significant Difference) at $5 \%$ for fetal body weight showed that all treatments have significant differences except for 12 and 16 hours exposed treatment. The 5\% LSD for fetal body length showed that control group was different with all exposed treatments. However, 4 hours exposed treatment was not different with 8 hours exposed treatment, and between 12 and 16 hours exposed treatment give the similar effects.
\end{abstract}

Key Word: Radiation, fetal, mice (Mus musculus L.)

\section{PENDAHULUAN}

Medan elektromagnetik merupakan medan magnet dan medan listrik yang dihasilkan oleh alam dan peralatan elektronik yang bermuatan listrik. Manusia sebagai salah satu sistem biologi, dimungkinkan selalu terpajan oleh medan elektromagnet (Anies, 2003).

Gelombang elektromagnet yang dihasilkan oleh peralatan elektronik dapat mengakibatkan cacat mental karena saraf otak terganggu (Taufik, 2009). Pajanan medan elektromagnet juga dapat menimbulkan gangguan kesehatan pada berbagai sistem tubuh, seperti sistem saraf, sistem reproduksi, sistem endokrin, hipersensitivitas, sistem darah, kondisi psikologis, dan kardiovaskular (Riedlinger, 2004).

Radiasi gelombang listrik dan gelombang magnet dapat dipancarkan dari berbagai peralatan listrik (Fathony, 2011). Salah satu peralatan listrik yang memancarkan gelombang listrik dan gelombang magnet adalah lampu merkuri. Pada dasarnya, jenis sinar yang dihasilkan oleh lampu merkuri adalah radiasi ultraviolet yang harus diubah menjadi cahaya tampak dengan 
cara melapisi dinding bagian dalam bohlam dengan serbuk fosfor, sama halnya dengan lampu fluoresen (Hutahuruk, 1996).

Dampak radiasi medan elektromagnetik terhadap kesehatan pertama kali diketahui pada tahun 1972, yaitu ketika para peneliti Uni Soviet melaporkan bahwa mereka yang bekerja di bawah transmisi listrik tegangan tinggi menderita sakit yang berhubungan dengan sistem saraf seperti gangguan pola tidur, kelelahan, dan sakit kepala (Anies, 2003).

Pemajanan medan elektromagnetik berfrekuensi sangat rendah dapat menyebabkan efek buruk pada kehamilan mencit dan gangguan perkembangan pada keturunannya. Pemajanan gelombang elektromagmetik dapat menyebabkan abortus spontan, terutama pada 9 minggu pertama kehamilan dan menye-babkan malformasi fetus (Valentine, 2009).

\section{BAHAN dan METODE}

Penelitian ini dilaksanakan di Laboratorium Zoologi Jurusan Biologi FMIPA Universitas Lampung dari bulan Oktober sampai November 2012.

Mencit yang akan diteliti ditempatkan dalam kandang mencit dengan ukuran $40 \times 50 \mathrm{~cm}$ untuk satu ekor mencit dan dilakukan aklimatisasi di laboratorium selama satu minggu. Mencit betina yang sedang estrus dikandangkan bersama mencit jantan dengan perbandingan $1: 4$ agar terjadi perkawinan dan jika ditemukan sumbat vagina keesokan harinya, maka mencit dianggap berada pada kehamilan hari pertama. Mencit yang telah gestasi dipisahkan dan yang belum kawin dicampur kembali dengan mencit jantan (Almahdy, 2007).
Penelitian ini menggunakan pemajanan lampu merkuri sebagai perlakuan. Dua puluh ekor mencit betina yang gestasi dibagi ke dalam lima kelompok, masing-masing terdiri dari 4 ekor mencit. Kelima kelompok tersebut meliputi; Kelompok kontrol yaitu tidak diberi perlakuan. Kelompok I, diberi perlakuan pemajanan lampu merkuri 4 jam perhari selama 18 hari. Kelompok II, diberi perlakuan pemajanan lampu merkuri 8 jam perhari selama 18 hari. Kelompok III, diberi pemajanan lampu merkuri 12 jam perhari selama 18 hari. Kelompok IV, diberi perlakuan pemajanan lampu merkuri 16 jam perhari selama 18 hari.

Pada hari ke-18 seluruh mencit yang diberi perlakuan dibius dengan kloroform kemudian dilakukan laparaktomi untuk mengeluarkan fetus dengan cara membedah abdomen ke arah atas sampai terlihat uterus yang berisi fetus. Fetus dikeluarkan dengan cara memotong uterus dan plasenta. Setelah fetus dikeringkan dengan kertas tisue lalu ditimbang sehingga diperoleh berat kelahiran.

Pada penelitian ini parameter yang diukur adalah bobot badan fetus dan panjang fetus mencit, yaitu jarak dari dahi sampai pangkal ekor fetus (Wijayanti et.al. 2008).

Untuk mengetahui ada tidaknya perbedaan antar perlakuan dilakukan uji Analisis Ragam. Apabila terjadi perbedaan yang nyata maka dilakukan uji Beda Nyata Terkecil pada taraf $5 \%$.

\section{HASIL dan PEMBAHASAN}

Berdasarkan penelitian yang telah dilakukan pada lima kelompok percobaan, maka diperoleh rerata berat badan fetus mencit yang tersaji pada Tabel 1.

Tabel 1. Rata-rata berat fetus yang induknya diberi pemajanan lampu merkuri selama 18 hari

\begin{tabular}{|c|c|c|c|c|c|}
\hline $\begin{array}{c}\text { Lama } \\
\text { pemajanan } \\
\text { (jam/hari) }\end{array}$ & \multicolumn{4}{|c|}{ berat fetus (gram) } & \multirow{2}{*}{$\begin{array}{c}\text { Rerata } \pm \mathrm{sd} \\
\text { (gram) }\end{array}$} \\
\cline { 2 - 5 } & 1 & 2 & 3 & 4 & $1,45 \pm 0,02$ \\
\hline 0 & 1,46 & 1,47 & 1,42 & 1,46 & 1,46 \\
\hline 4 & 1,32 & 1,23 & 1,26 & 1,18 & $1,24 \pm 0,05$ \\
\hline 8 & 1,11 & 1,09 & 1,15 & - & $1,12 \pm 0,03$ \\
\hline 12 & 0,97 & 0,95 & 0,97 & - & $0,96 \pm 0,01$ \\
\hline 16 & 0,95 & 0,93 & 0,96 & 0,94 & $0,94 \pm 0,01$ \\
\hline
\end{tabular}

Secara umum telihat bahwa pemajanan lampu merkuri mengakibatkan penurunan rata-rata berat fetus (Tabel 1). Pada perlakuan 8 dan 12 jam/hari terdapat mencit yang tidak menghasil- kan fetus. Ketidakberhasilan mencit menghasilkan fetus diduga disebabkan oleh kondisi mencit yang memang infertil atau mencit tersebut mengalami gangguan pada saat proses 
perkembangan fetus karena pemajanan lampu merkuri sehingga perkembangan fetus terhenti. Semua makhluk hidup sangat sensitif terhadap segala bentuk radisi selama tahap embrionik. Pada periode pembuahan apabila embrio atau fetus terkena radiasi dapat menimbulkan kematian atau gangguan kongenital (Valentine, 2009). Pada embrio, kehilangan sejumlah kecil sel akan sangat berpengaruh. Jika sebagian sel mati pada periode perkembangan awal embrio maka sel yang tersisa terlalu sedikit untuk dapat menghasilkan organisme hidup, sehingga terjadi kematian intrauterin.

Dari hasil uji analisis ragam diketahui bahwa pemajanan dengan lampu merkuri memberikan pengaruh yang bermakna (positif), hal ini ditunjukkan oleh $F_{h}<F_{t}$ yang berarti pemajanan radiasi lampu merkuri dengan lama waktu berbeda memberikan pengaruh yang nyata.

Dari hasil uji lanjut diperoleh hasil bahwa semua perlakuan memiliki pengaruh yang berbeda, kecuali pada perlakuan pemajanan 12 jam/hari dan 16 jam/hari menunjukkan pengaruh yang tidak berbeda.

Radiasi yang ditimbulkan oleh cahaya lampu mengakibatkan turunnya berat badan fetus mencit seiiring dengan semakin lama waktu pemajanan. Perubahan berat badan fetus merupakan parameter yang penting untuk mengetahui pengaruh dari senyawa asing terhadap fetus. Laju pertumbuhan dan perkembangan fetus menentukan variasi ukuran anakan. Rerata berat fetus normal pada usia kebuntingan adalah 1,4 gram (Wilson and Warkany, 1975).

Penurunan berat fetus diduga terjadi karena induk mencit mengalami stres. Di dalam tubuh makhluk hidup terdapat medan listrik endogen yang berperan kompleks dalam mengontrol mekanisme fisiologi tubuh. Apabila terdapat medan listrik yang lebih besar di sekitarnya akan mempengaruhi medan listrik endogen. Pemajanan radiasi dari luar akan mengakibatkan stres bagi tubuh dan mengakibatkan kelelahan. Radiasi cahaya lampu yang berkepanjangan akan menyebabkan mencit menjadi depresi dan hipokampus menjadi abnormal. Keadaan tersebut akan menghasilkan hormon adrenalin yang berlebihan sehingga mempengaruhi dan mengganggu sistem homeostatis tubuh. Stres pada induk mencit dapat diakibatkan oleh berbagai hal seperti lingkungan kandang yang kotor. Faktor makanan yang diberikan hanya satu jenis juga dapat menurunkan berat fetus karena kekurangan nutrisi serta ruang yang tertutup sehingga sirkulasi udara tidak berjalan dengan baik.

\section{Panjang Tubuh Fetus Mencit}

Dari pengukuran panjang tubuh fetus mencit, dapat dilihat perbedaan panjang tubuh antar perlakuan (Gambar 1).

Sama halnya dengan perhitungan berat fetus, panjang fetus didapat dengan mengukur panjang fetus yang dihasilkan tiap induk kemudian dihitung rata-ratanya dan selanjutnya dihitung rata-rata panjang fetus tiap kelompok. Hasil perhitungan nilai rata-rata panjang fetus menunjukkan bahwa panjang mencit pada kelompok perlakuan pemajanan lebih pendek dibandingkan dengan kontrol (Tabel 2).

Hasil analisis ragam menunjukkan terdapat perbedaan yang signifikan antar perlakuan dan uji lanjut BNT $\alpha=5 \%$ menunjukkan bahwa kontrol berbeda dengan semua perlakuan pemajanan. Pemajanan 4 jam/hari tidak berbeda nyata dengan pemajanan 8 jam/hari, dan pemajanan 12 jam/hari dan pemajanan 16 jam/hari menunjukkan pengaruh yang tidak berbeda nyata.

Tabel 2. Rata-rata panjang fetus $(\mathrm{cm})$ yang induknya diberi pemajanan lampu merkuri selama 18 hari

\begin{tabular}{|c|c|c|c|c|c|}
\hline \multirow{2}{*}{$\begin{array}{c}\text { Lama pemajanan } \\
\text { (jam/hari) }\end{array}$} & \multicolumn{4}{|c|}{ Panjang fetus (cm) } & \multirow{2}{*}{$\begin{array}{c}\text { Rerata } \\
\text { sd (cm) }\end{array}$} \\
\cline { 2 - 5 } & 1 & 2 & 3 & 4 & $\overline{\mathrm{x}} \pm$ sd \\
\hline 0 & 2,66 & 2,68 & 2,74 & 2,70 & $2,69 \pm 0,03$ \\
\hline 4 & 2,66 & 2,51 & 2,47 & 2,50 & $2,53 \pm 0,08$ \\
\hline 8 & 2,47 & 2,35 & 2,51 & - & $1,83 \pm 0,08$ \\
\hline 12 & 2,23 & 2,08 & 2,25 & - & $1,64 \pm 0,09$ \\
\hline 16 & 2,17 & 2,1 & 2,08 & 2,12 & $2,11 \pm 0,03$ \\
\hline
\end{tabular}

Kelainan intrauterine dapat menghasilkan embrio cacat. Penyebab kelainan perkembangan embrio yang dibawa sejak lahir dapat dipengaruhi oleh faktor genetik dan nirgenetis atau lingkungan seperti zat kimia, radiasi, penyakit dan lain sebagainya (Sukra, 2000). Faktor-faktor tersebut apabila terinduksikan pada induk mencit bunting dapat mempengaruhi proses embriogenesis dan organogenesis sehingga muncul malformasi. Pemendekkan pada tubuh 
fetus mencit diduga disebabkan oleh efek teratogen yang muncul akibat radiasi dari lampu sehingga menghambat proses osifikasi pada masa organogenesis. Terhambatnya osifikasi tersebut mungkin disebabkan oleh radiasi yang mengganggu potensial membran dan transport ion kalsium. Akibatnya mengganggu pembentukan DNA dan RNA dan menyebabkan terhambatnya mitosis pada zona proliferasi, kegagalan interaksi, degenerasi sel kondrosit, dan kematian (Wilson, 1973).

Mortalitas dan abnormalitas (Gambar 2) pada fetus diduga akibat langsung dari pengaruh pemajanan cahaya lampu terhadap induk, sehingga mengganggu perkembangan fetus, yaitu terganggunya proses pembelahan, kegagalan implantasi embrio akibat kerusakan uterus, dan rusaknya sel akibat senyawa teratogen (Panjaitan, 2003).

Kelainan perkembangan embrio juga dapat terjadi karena faktor genetik yang berupa mutasi dan aberasi. Faktor lingkungan seperti infeksi, obat, dan defisiensi juga dapat mengakibatkan kelainan perkembangan (Yatim, 1994)

Dalam penelitian ini ditemukan kematian fetus pada dua induk mencit. Pada pemajanan lampu merkuri selama 12 jam/hari ditemukan embrio yang mengalami kematian awal (resorpsi) yaitu fetus mengalami kematian ketika berada dalam uterus dan berwarna putih pucat serta lunak (Gambar 3). Kematian awal dapat diakibatkan oleh kematian sel-sel yang menyusun sel dalam tubuh. Efek radiasi inutero pada janin dapat berupa anak dengan ukuran tubuh kecil dan pertumbuhannya tidak sem-purna atau mengakibatkan kematian sel. Jika sebagian sel mati pada periode perkembangan awal janin maka sel yang tersisa terlalu sedikit untuk meng-hasilkan organisme hidup (Rugh, 1968).

Setiap induk mencit memiliki tingkat ketahanan tubuh yang berbeda-beda. Kerusakan yang terjadi tentu akan berbeda-beda tergantung kerentanan organ tubuh sasaran dan kondisi keseluruhan. Bagian tertentu alat tubuh akan menderita lebih parah jika bagian tersebut memiliki gradien fisiologi tinggi. Apabila keseimbangan gradien fisiologi pada bagian tubuh embrio terganggu karena masuknya senyawa atau radiasi maka pengaruh tersebut menghambat pertumbuhan embrio (Sukra, 2000).

\section{KESIMPULAN}

Pemajanan lampu merkuri selama 4 jam/hari, 8 jam/hari, 12 jam/hari, dan 16 jam/hari terhadap induk mencit bunting menyebabkan penurunan berat badan fetus dan panjang tubuh fetus.

\section{DAFTAR PUSTAKA}

Almahdy, A. 2007. Teratogenic and fertility evaluation of safrole on mice, Artocarpus, 7, (1), 49-53.

Anies. 2003. Gangguan kesehatan pada keluarga yang bertempat tinggal di bawah saluran udara extra tinggi $500 \mathrm{kV}$. Jurnal Kedokteran YARSI. 9: 2-101.

Fathony, M. 2011. Radiasi Elektro-magnetik dari Alat Elektronik dan Efeknya bagi Kesehatan. Kepala Bidang Dosimetri, Puslitbang Keselamatan Radiasi dan Biomedika Nuklir, Batan.

Hutahuruk, T.S. 1996. Transmisi Daya Listrik. Erlangga, Jakarta.

Panjaitan, R.G.P. 2003. Bahaya Gagal Hamil yang Diakibatkan Minuman Beralkohol. http://tumuotou,net/702-07134/ruqiahgp.htm. Diakses tanggal 20 Juni 2012.

Riedlinger. 2004. Virtual environments. www.rics.org/NR/rdonlyres/C184EA66ED72-4597-8497-D02039286652/0/ Virtual_environments20051202.pdf

Rugh, R. 1968. The Mouse: It's Reproduction and Development. Burgess Publishing Co. Minneapolis.

Sukra, Y. 2000. Wawasan Pengetahuan Embrio: Benih Masa Depan. Departemen Pendidikan Nasional. Jakarta.

Taufik. 2009. Peranan Elektronik pada Komunikasi. (http://akyurakun.blogspot.com). Diakses 7 Juni 2012.

Valentine, C. 2009. Pengaruh Pemajanan Medan Elektromag-netik Extremely Low Frequency Secara Kontinu Terhadap Perubahan Siklus Estrus Mencit (Mus musculus L.) Str ain Swiss Webster (Skripsi). Universitas Indonesia. Jakarta.

Wijayanti, E.D., B.P. Soenardiraharjo, B. dan Utomo. 2008. Pengaruh Pemberian Ekstrak Daun Api-Api (Avicennia marina) terhadap Resorpsi Embrio, Berat Badan dan Panjang Badan Janin Mencit (Mus musculus). Fakultas Kedokteran Hewan Universitas Airlangga. Surabaya.

Wilson, J.G. 1973. Environment and Birth Defects. Academic Press, New York. Pp.6-8.

Wilson, J.G. and J. Warkany. 1975. Teratology Principles and Techniques. University of Chicago Press. Chicago.

Yatim, W. 1994. Reproduksi dan Embriologi.Tarsito. Bandung. 


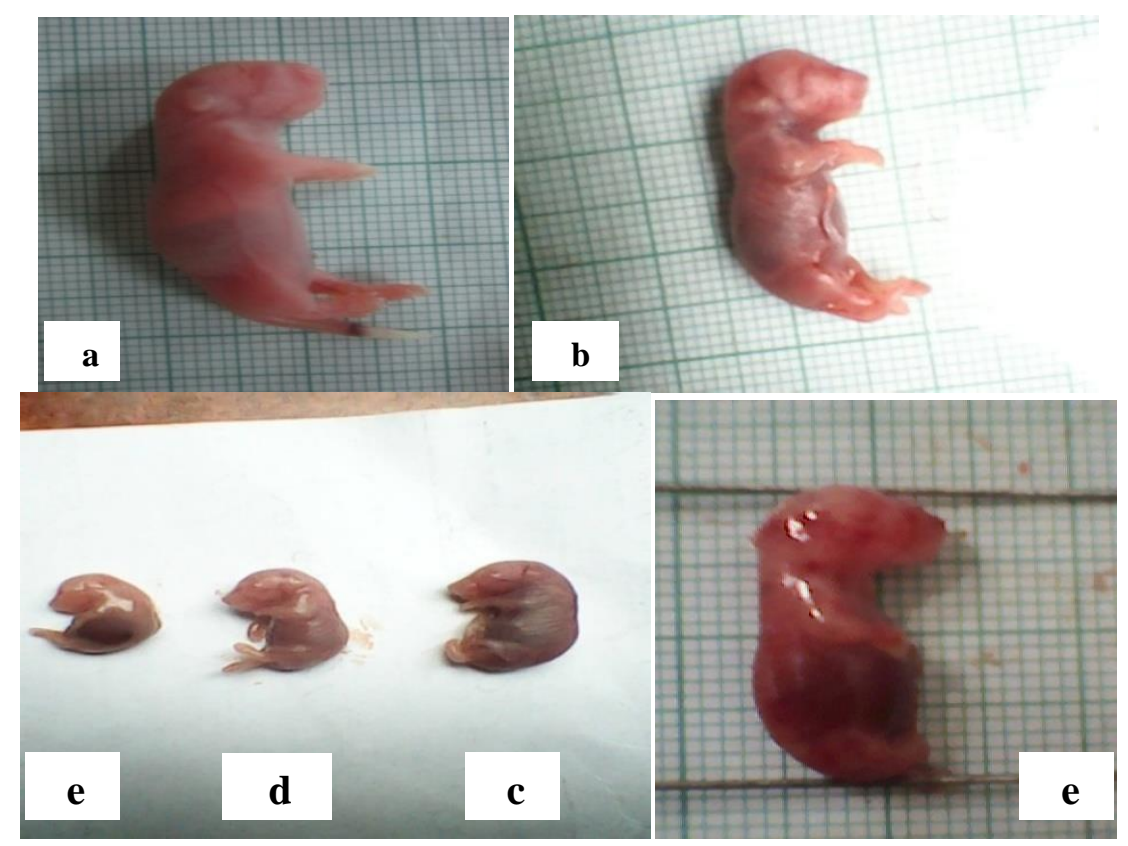

Gambar 1. Morfologi fetus mencit yang induknya diberi pemajanan lampu merkuri (a) 0 jam/hari (kontrol), (b) 4 jam/hari, (c) 8 jam/hari, (d) 12 jam/hari, dan (e) 16 jam/hari selama 18 hari

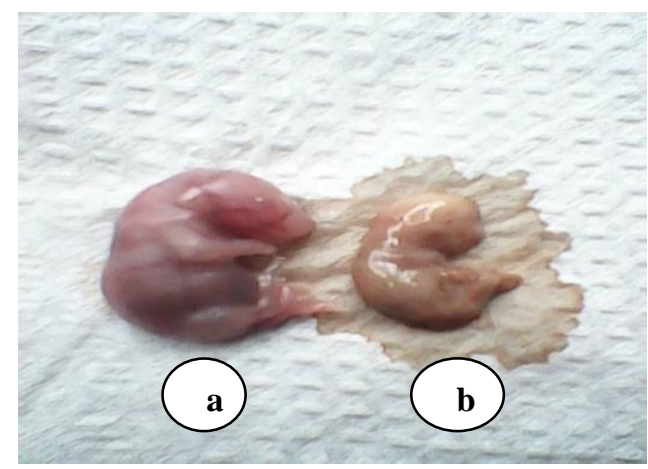

Gambar 2. (a) Fetus mencit normal, (b) Mortalitas fetus mencit pada perlakuan 16 jam/hari

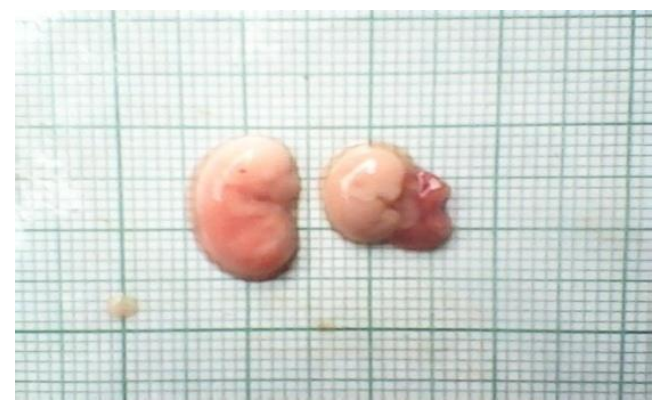

Gambar 3. Fetus yang mengalami kematian dalam uterus pada pemajanan 12 jam/hari 